\title{
Correction: Rodríguez-Medellín, R., et al. Mexican Validation of the Engagement and Disaffection in Physical Education Scale. Int. J. Environ. Res. Public Health 2020, 17, 1821
}

\author{
René Rodríguez-Medellín ${ }^{1}$, Jorge Zamarripa ${ }^{1, * \mathbb{D}}$, María Marentes-Castillo ${ }^{1}$, Fernando Otero-Saborido ${ }^{2}$, \\ Raúl Baños $^{3}$ (D) and Raquel Morquecho-Sánchez ${ }^{1}$ \\ 1 Faculty of Sports Organization, Autonomous University of Nuevo Leon, Cd. Universitaria, s/n, \\ San Nicolás de los Garza, Nuevo Leon 66451, Mexico; rene.rodriguezmd@uanl.edu.mx (R.R.-M.); \\ salette.marentescs@uanl.edu.mx (M.M.-C.); raquel.morquechosn@uanl.edu.mx (R.M.-S.) \\ 2 Faculty of Sports Sciences, Pablo de Olavide University, Ctra. de Utrera, 1, 41013 Sevilla, Spain; \\ fmotero@upo.es \\ 3 Campus Ensenada, Faculty of Sports, Autonomous University of Baja California, Paseo de la Playa, \\ Carlos Pacheco 7, Ensenada 22890, Mexico; raulfb89@gmail.com \\ * Correspondence: jorge.zamarriparv@uanl.edu.mx
}

check for updates

Citation: Rodríguez-Medellín, R.; Zamarripa, J.; Marentes-Castillo, M.; Otero-Saborido, F.; Baños, R.; Morquecho-Sánchez, R. Correction: Rodríguez-Medellín, R., et al. Mexican Validation of the Engagement and Disaffection in Physical Education Scale. Int. J. Environ. Res. Public Health 2020, 17, 1821. Int. J. Environ. Res. Public Health 2021, 18, 782. https://doi.org/ $10.3390 /$ ijerph18020782

Received: 22 December 2020 Accepted: 15 January 2021 Published: 18 January 2021

Publisher's Note: MDPI stays neutral with regard to jurisdictional clai$\mathrm{ms}$ in published maps and institutional affiliations.

Copyright: (C) 2021 by the authors. Licensee MDPI, Basel, Switzerland. This article is an open access article distributed under the terms and conditions of the Creative Commons Attribution (CC BY) license (https:// creativecommons.org/licenses/by/ $4.0 /)$.
The authors wish to add the following correction to their paper published in International Journal of Environmental Research and Public Health [1].

In row 2 of Table 1 (page 5), "Emotional engagement" appears in italics, this should instead be "Behavioral engagement".

In row 7 of Table 1 (page 5), "Behavioral engagement" appears in italics, this should instead be "Emotional engagement".

In row 15 of Table 1 (page 5), "Emotional disaffection" appears in italics, this should instead be "Behavioral disaffection".

In row 21 of Table 1 (page 5), "Behavioral disaffection" appears in italics, this should instead be "Emotional disaffection".

The authors would like to apologize for any confusion or inconvenience. Corrected Table 1 is presented below. 
Table 1. The standardized solution of the four sub-scales of the instrument.

\begin{tabular}{|c|c|c|c|c|c|c|c|}
\hline \multirow{2}{*}{\multicolumn{2}{|c|}{ Sub-Scales }} & \multirow{2}{*}{$M$} & \multirow{2}{*}{$S D$} & \multirow{2}{*}{ Asymmetry } & \multirow{2}{*}{ Kurtosis } & \multicolumn{2}{|c|}{ Factorial Saturations } \\
\hline & & & & & & 2 Factors & 4 Factors \\
\hline \multicolumn{2}{|c|}{ Engagement } & 4.10 & 0.72 & -1.10 & 1.49 & & \\
\hline & Behavioral engagement & 4.21 & 0.85 & -1.26 & 1.33 & & \\
\hline 2 & I study for my physical education class (Estudio para la clase de educación física) & 3.25 & 1.51 & -0.35 & -1.32 & 0.24 & 0.26 \\
\hline \multirow[t]{2}{*}{3} & I try to do the most I can in the physical education class (Trato de hacer lo más que pueda en la clase de educación física) & 4.35 & 0.98 & -1.62 & 2.12 & 0.74 & 0.80 \\
\hline & Emotional engagement & 3.99 & 0.82 & -0.78 & 0.49 & & \\
\hline 4 & I enjoy the time I spend in the physical education class (Disfruto del tiempo que paso en la clase de educación fisica) & 4.42 & 1.00 & -1.90 & 3.01 & 0.77 & 0.79 \\
\hline 6 & $\begin{array}{l}\text { The content we see in the physical education class is interesting (Es interesante el contenido que vemos en la clase de } \\
\text { educación física) }\end{array}$ & 4.12 & 1.16 & -1.28 & 0.74 & 0.69 & 0.69 \\
\hline \multicolumn{2}{|r|}{ Disaffection } & 2.21 & 1.05 & 0.72 & -0.34 & & \\
\hline & Behavioral disaffection & 1.93 & 1.20 & 1.09 & -0.07 & & \\
\hline 7 & It is difficult to attend the physical education class (Es difícil asistir a la clase de educación física) & 2.25 & 1.50 & 0.72 & -1.04 & 0.61 & 0.71 \\
\hline 8 & I only do enough to pass the physical education class (Sólo hago lo suficiente para pasar en la clase de educación física) & 2.85 & 1.60 & 0.09 & -1.56 & 0.44 & 0.59 \\
\hline \multirow[t]{2}{*}{9} & I do not do much work outside the physical education class (No hago mucho trabajo fuera de la clase de educación física) & 2.35 & 1.48 & 0.60 & -1.12 & 0.66 & 0.78 \\
\hline & Emotional disaffection & 1.93 & 1.20 & 1.09 & -0.07 & & \\
\hline 11 & The physical education class stresses me (Me estresa la clase de educación física) & 2.00 & 1.41 & 1.09 & -0.33 & 0.86 & 0.86 \\
\hline 12 & Being in the physical education class is a waste of time (Es una pérdida de tiempo estar en la clase de educación física) & 1.81 & 1.34 & 1.43 & 0.57 & 0.90 & 0.91 \\
\hline
\end{tabular}

Note: $M-$ Mean; $S D$-Standard Deviation. All saturations were significant, $t>1.96, p<0.05$. 


\section{Reference}

1. Rodríguez-Medellín, R.; Zamarripa, J.; Marentes-Castillo, M.; Otero-Saborido, F.; Baños, R.; Morquecho-Sánchez, R. Mexican Validation of the Engagement and Disaffection in Physical Education Scale. Int. J. Environ. Res. Public Health 2020, $17,1821$. [CrossRef] 